$\frac{\mathrm{DE}}{\mathrm{G}}$

DE GUVTER

\title{
STEADY- STATE THREE - DIMENSIONAL NUMERICAL SIMULATION OF HEAT TRANSFER FOR THERMAL BRIDGES ASSESSMENT
}

\author{
Silviana Brata $^{\text {a, }}$, Carmen Maduta $^{\text {a }}$, S. Pescari ${ }^{\text {a }}$ \\ ${ }^{a}$ Politehnica University of Timisoara, Faculty of Civil Engineering, Civil Engineering and Services Department, 2 Traian Lalescu \\ Street, Timisoara, Romania
}

Received: 09.03.2016 / Accepted: 15.04.2016 / Revised: 21.05.2016 / Available online: 31.05 .2016

DOI: 10.1515/jaes-2016-0008

KEY WORDS: thermal bridges, building elements, three-dimensional heat transfer, heat flow, linear thermal transmittance

\begin{abstract}
:
This paper presents a study on using the steady-state three-dimensional heat transfer software HEAT3 for evaluating the heat flow of heat transfer through different elements of the building envelope in order to establish the linear thermal transmittance of the linear thermal bridge. The linear thermal transmittance is obtained according to the one-dimensional steady- state heat transfer calculation formula for the plane walls using the heat flow values obtained through the method specified above. The results presented in this paper are part of a wider study on evaluating the heat transfer through building's envelope elements by evaluating as accurate as possible the thermal bridges effect of the most common building structures. As a case study, it was considered the steady-state heat transfer through an opaque outer wall of a building considering the thermal bridges for the following elements: outer walls intersection, inner and outer wall intersection and outer wall with intermediate floor intersection.
\end{abstract}

\section{INTRODUCTION}

In 2003 came out the 2002/91/EC Directive on the energy performance of buildings (EPBD) which was transposed, in Romania, into Law 372/2005 (Law 372, 2005; Mc001, 2006). Among other measures, an important outcome of the Law $372 / 2005$ implementation is creating a legal framework for existing building stock assessment. The Romanian methodology Mc001/2006 (Mc001,2006), for determining the energy performance of buildings was developed in compliance with the Law 372/2005 and is based on the European standard package specific to this field.

The Romanian methodology Mc001/ 2006 (Mc001, 2006) for determining the energy performance of buildings provides stipulations to design energy efficient buildings but also provides solutions and methods for assessing the condition of existing buildings and their energy consumption. Currently, increasing the energy efficiency in the building sector is heading largely on the rehabilitation of existing buildings stock. In this context, research is focused on finding solutions to determine the existing building's performance as accurate as possible (Pescari, 2013).
Typically, the energy consumption evaluation and the transmission heat losses evaluation are based on using the corrected thermal resistances of each envelope element. Corrected thermal resistances are the thermal resistance determined in the current field of the envelope elements, namely the sum of all layers thermal resistances, considering the thermal bridges influence reductions (Pescari, 2015). These reductions are evaluated according to Mc001/2006 and Buildings Thermal Bridges Catalogue based on approximations and similarities between different examples and real situations. Often these approximations do not lead to accurate results.

This paper is part of a wider study that is intended to evaluate the heat transfer through the elements of the building envelope using three-dimensional steady-state heat transfer software such as HEAT3 in order to accurately assess the effect of the thermal bridges.

\section{MATHEMATICAL MODELS}

\subsection{Steady-state one- and three-dimensional heat transfer}

The differential equation of thermal conduction in three dimensions is given, in generally, by the following relationship:

\footnotetext{
* Silviana BRATA, Politehnica University of Timisoara, email: silviana.brata@upt.ro
} 


$$
\frac{\partial t}{\partial \tau}=\frac{1}{\rho c}\left[\frac{\partial}{\partial x}\left(\lambda_{x} \frac{\partial t}{\partial x}\right)+\frac{\partial}{\partial y}\left(\lambda_{y} \frac{\partial t}{\partial y}\right)+\frac{\partial}{\partial z}\left(\lambda_{z} \frac{\partial t}{\partial z}\right)\right]+\frac{q_{v}}{\rho c}
$$

where: $\lambda_{x}, \lambda_{y}, \lambda_{z}=$ the thermal conductivities of the material in three dimensions, in $\mathrm{W} /(\mathrm{mK})$

$\rho=$ the density of the material, in $\mathrm{kg} / \mathrm{m}^{3}$;

$c=$ the mass heat capacity, in $\mathrm{J} /(\mathrm{kg} \mathrm{K})$;

$q_{\mathrm{v}}=$ the contribution of the internal sources of heat, in $\mathrm{W} / \mathrm{m}^{3}$.

Usually, the thermal conductivity $\lambda$ is considered constant after the three directions and the internal sources of heat, zero. Thus the relationship (1) becomes:

$$
\frac{\partial t}{\partial \tau}=\frac{\lambda}{\rho c}\left[\left(\frac{\partial^{2} t}{\partial x^{2}}+\frac{\partial^{2} t}{\partial y^{2}}+\frac{\partial^{2} t}{\partial z^{2}}\right)\right]
$$

In steady-state heat transfer, the thermal conduction differential equation is given by the following relationship:

$$
\frac{\partial^{2} t}{\partial x^{2}}+\frac{\partial^{2} t}{\partial y^{2}}+\frac{\partial^{2} t}{\partial z^{2}}=0
$$

Differential equation solving can be achieved by applying the finite difference method or the finite element method. The boundary conditions are:

- Boundary conditions of Fourier type, expressing that heat flow that is passed by the heat conduction in solid and reached solidliquid separation surface is taken up entirely by convection and radiation.

Heat transmission by the solid-liquid separation surface is given by Newton's law:

$$
q=h\left(t_{s}-t_{f}\right)
$$

where: $h=$ the surface heat transfer coefficient, in $\mathrm{W} /(\mathrm{m} 2 \mathrm{~K})$, and contains both a convective and a radiant component:

$$
h=h_{\text {conv }}+h_{\text {rad }}
$$

It results:

$$
q=-\lambda\left(\frac{d t}{d x}\right)_{s}=h\left(t_{s}-t_{f}\right)
$$

- Contact boundary conditions, stating that the surface of separation between two solids does not change heat flow value, thus expresses a conservation law of conductive heat flow:

$$
q=-\lambda_{1}\left(\frac{d t_{1}}{d x}\right)_{s}=-\lambda_{2}\left(\frac{d t_{2}}{d x}\right)_{s}
$$

\subsection{HEAT3 software}

HEAT3 is a program used for three dimensional transient and steady-state heat transfer. The program can be used for assessing the heat transfer through different building envelope configuration and also for thermal bridges evaluation. An important restriction of the program is that any configurations must be described in a parallelepipedical mesh meaning that all internal and external boundaries are parallel with of the $\mathrm{x}, \mathrm{y}, \mathrm{z}$ directions. Thus, a network of cells is proposed to describe the geometry of the three dimensional studied building element (Blomberg, 2012; Brata, 2016).

The heat equation is replaced by a discrete approximation. The temperature field is approximated by values at discrete points (Blomberg, 2012; Brata, 2016). An energy balance is made for each described cell. The steady-state method is based on the successive over-relaxation method. The temperatures are calculated in the same way as with explicit forward difference, but new temperatures are used in the formulas as they arise. A significant fact is that the heat capacities of the cells do not matter in this case (Blomberg, 2012; Brata, 2016). In order to highlight the effects of thermal bridges using HEAT3 or any other software in fact, modelling the entire building is challenging or even impossible; therefore the building is divided into several elements using sectioning plans. This division is carried out so as to avoid any difference in the calculation results for the building as a whole and the building divided into several elements. The building's components modelling is made in accordance with the requirements of EN ISO 10211- 2008. In the following cases, for accurate calculations, the sectioning plans were chosen to cover a distance $\mathrm{d}=1.20 \mathrm{~m}$ from the central element (recommended $1.00 \mathrm{~m}$ or 3 times the thickness of the lateral element, being chosen the highest value).

\subsection{Linear thermal transmittance evaluation}

According to Romanian methodology Mc001/2006 the heat flow is calculated using the steady state transmittance (Pescari, 2015).

$$
\Phi=\mathrm{L}_{\mathrm{J}} \times \Delta \theta
$$

where: $\mathrm{L}_{\mathrm{J}}=$ the steady state transmittance,

$\Delta \theta=$ the difference between interior and exterior temperature.

$$
\mathrm{L}_{\mathrm{J}}=\frac{A_{j}}{R_{j}}
$$

where: $A_{J}=$ envelope elements areas calculated considering the interior dimensions of the envelope elements,

$R_{\mathrm{j}}^{\prime}=$ corrected thermal resistance (uni-dimensional calculation).

$$
R^{\prime}=r \times R
$$

$$
r=\frac{1}{1 \frac{\left.R \times\left[\sum \psi \times l\right)+\sum \lambda\right]}{A}}
$$

\section{STUDY CASE}

The study was conducted for three types of thermal bridges zones characteristic for the building's envelope, in two cases, thermal insulated and thermal un-insulated outer wall:

- Outer walls intersection

- Inner and outer wall intersection

- Outer wall with intermediate floor intersection 
The component materials in the structure of the envelope elements are characterized by the following parameters presented in table 1 .

\begin{tabular}{|c|c|c|c|}
\hline Layer & $\begin{array}{c}\text { Thickness } \\
d\end{array}$ & $\begin{array}{c}\text { Thermal } \\
\text { conductivity } \\
\lambda \\
\mathrm{W} /(\mathrm{mK})\end{array}$ & $\begin{array}{c}\text { Volumetric } \\
\text { thermal } \\
\text { capacity } \\
C_{\text {vol }} \\
\mathrm{MJ} /\left(\mathrm{m}^{3} \mathrm{~K}\right)\end{array}$ \\
\hline Interior plaster & 2 & 0.96 & 1.512 \\
\hline $\begin{array}{c}\text { Vertical hollow } \\
\text { masonry }\end{array}$ & 25 & 0.33 & 1.262 \\
\hline $\begin{array}{c}\text { Thermal } \\
\text { insulation }\end{array}$ & 10 & 0.062 & 0.075 \\
\hline Outer plaster & 3 & 0.9 & 1.428 \\
\hline Floor & 5 & 1.03 & 1.344 \\
\hline $\begin{array}{c}\text { Reinforced } \\
\text { concrete slab }\end{array}$ & 13 & 1.74 & 2.016 \\
\hline
\end{tabular}

Table 1. Materials parameter of the envelope elements

The considered boundary conditions are:

- Interior air: $\mathrm{t}=20^{\circ} \mathrm{C}$, interior superficial thermal resistance, $\mathrm{R}_{\mathrm{si}}=0.125\left(\mathrm{~m}^{2} \mathrm{~K}\right) / \mathrm{W}$;

- Exterior air, $\mathrm{t}=-15^{\circ} \mathrm{C}$, exterior superficial thermal resistance, $\mathrm{R}_{\mathrm{se}}=0.042\left(\mathrm{~m}^{2} \mathrm{~K}\right) / \mathrm{W}$;

- Adiabatic boundary in the plane of the walls and floors, outside of the considered surfaces. The surfaces are similar to those used in (Buildings Thermal Bridges Catalogue, 2012).

Further on are presented the results obtained with the software HEAT3 for the thermal bridge of outer walls intersection.

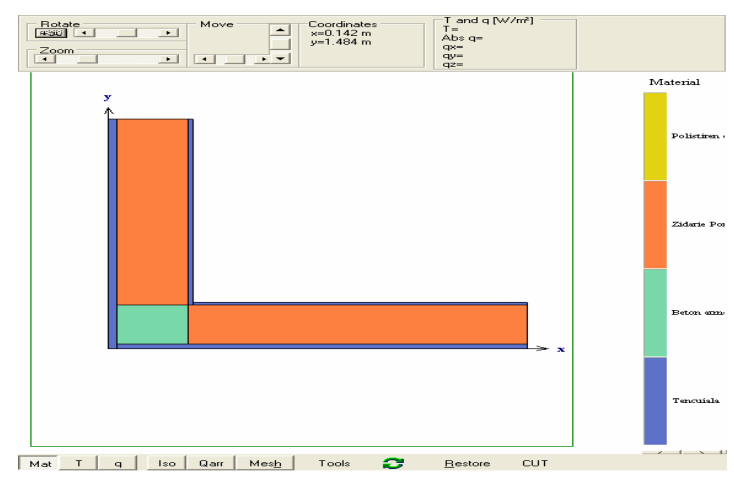

Figure 1a. Outer walls intersection (MATERIALS)

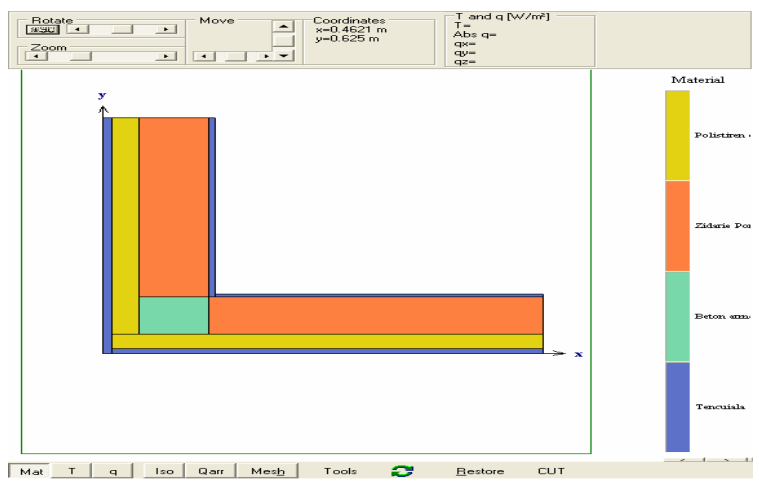

Figure 1b. Thermal insulated outer walls intersection (MATERIALS)
In figures $1 \mathrm{a}$ and $1 \mathrm{~b}$ are presented the geometric features and materials used in the composition of the envelope elements. The figures $2 \mathrm{a}, 2 \mathrm{~b}$ and $3 \mathrm{a}, 3 \mathrm{~b}$ show the two- and three-dimensional temperature fields, respectively, the figures $4 a, 4 b, 5 a$ and $5 b$, the density of heat flow distributions.

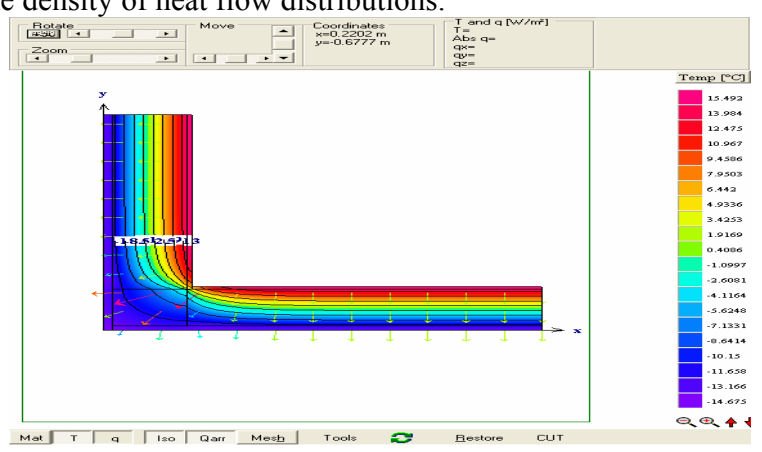

Figure 2a. Outer walls intersection (TWO DIMENSIONAL TEMPERATURE DISTRIBUTION)

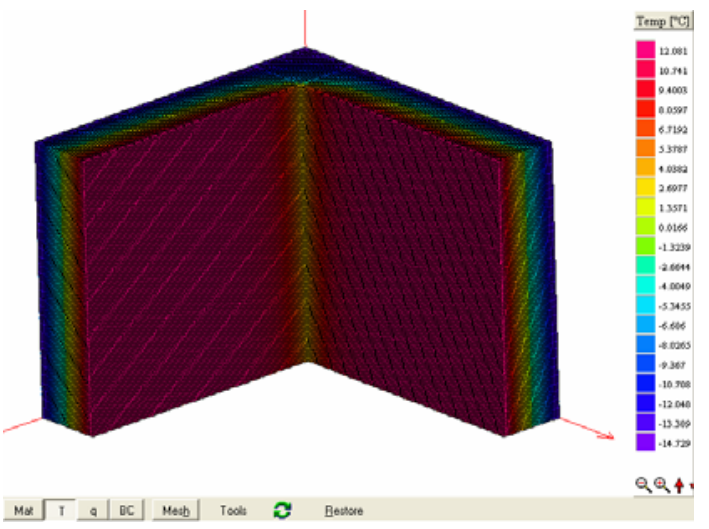

Figure 2b. Outer walls intersection (THREE DIMENSIONAL TEMPERATURE DISTRIBUTION)

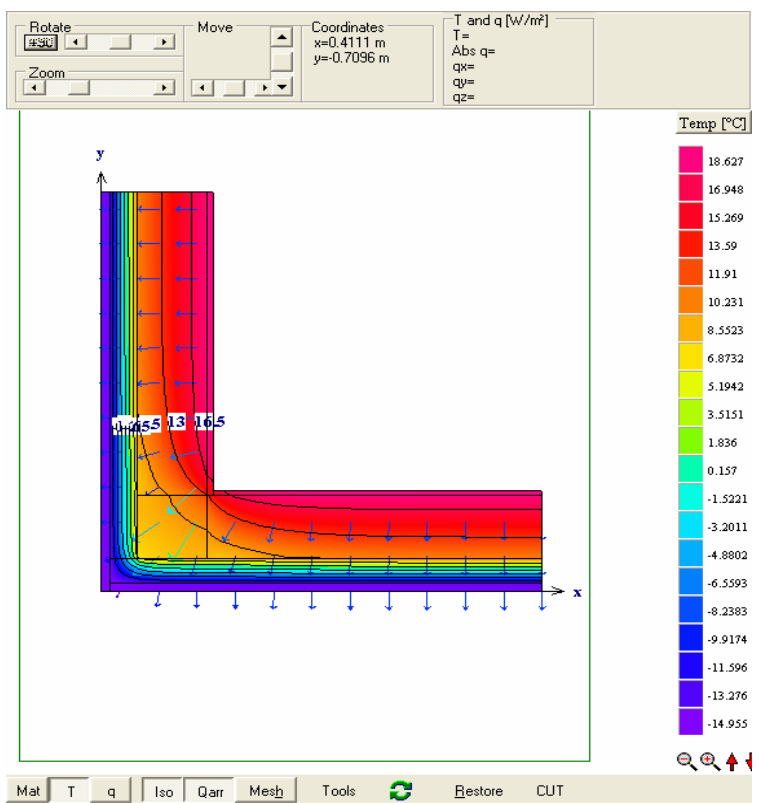

Figure 3a. Thermal insulated outer walls intersection (TWO- DIMENSIONAL TEMPERATURE DISTRIBUTION) 
$\overline{\mathrm{G}}$

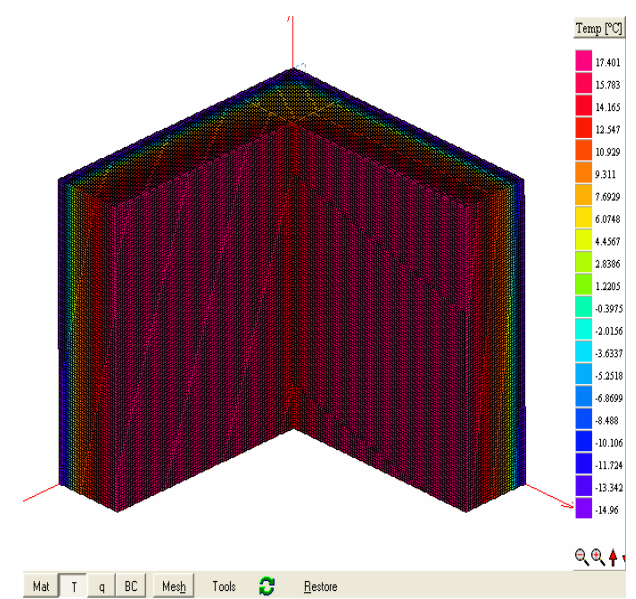

Figure $3 \mathrm{~b}$. Thermal insulated outer walls intersection (THREE DIMENSIONAL TEMPERATURE DISTRIBUTION)

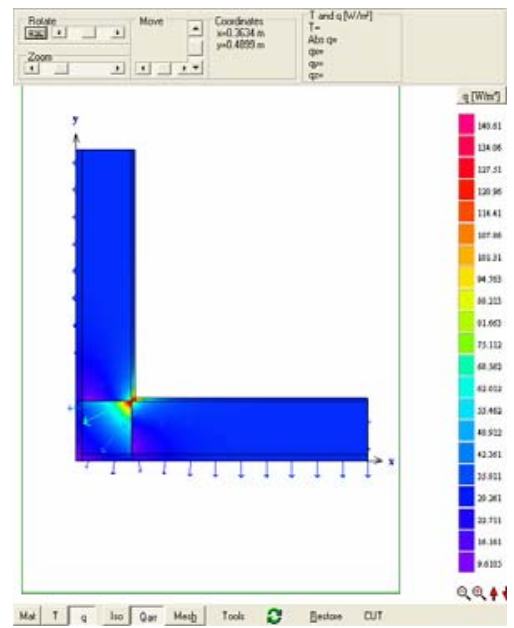

Figure 4a. Outer walls intersection (TWO DIMENSIONAL DENSITY OF HEAT FLOW DISTRIBUTION)

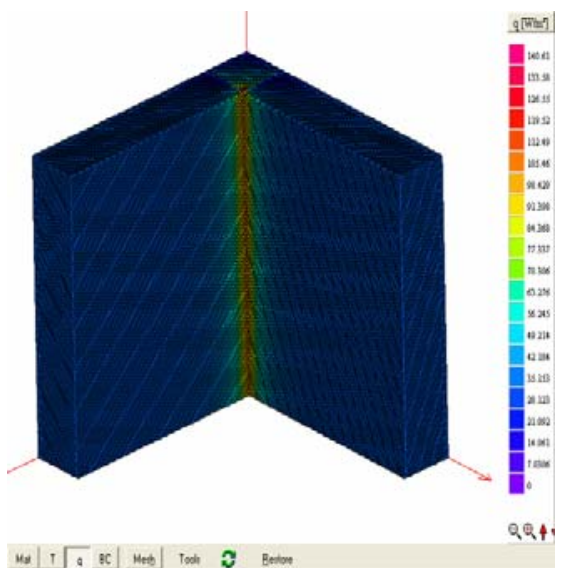

Figure 4b. Outer walls intersection (THREE DIMENSIONAL DENSITY OF HEAT FLOW DISTRIBUTION)

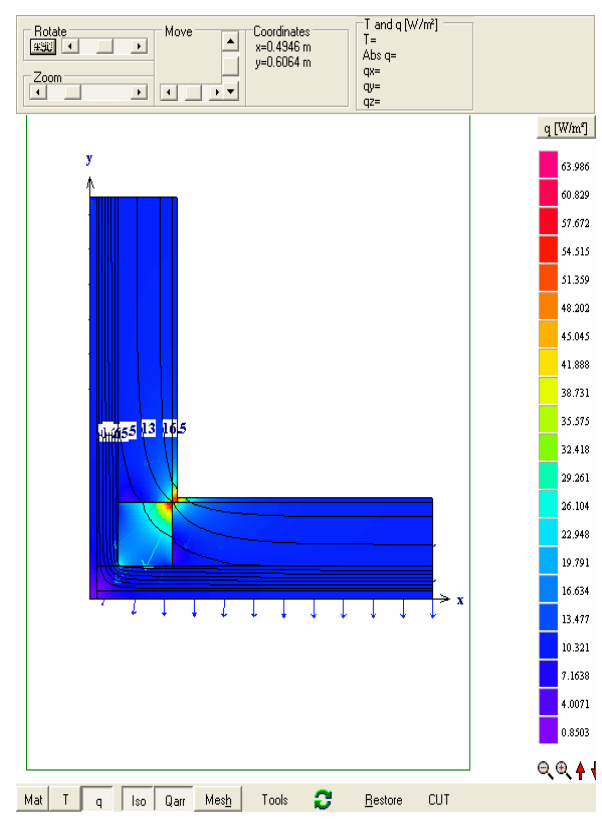

Figure 5a. Thermal insulated outer walls intersection (TWO DIMENSIONAL DENSITY OF HEAT FLOW DISTRIBUTION)

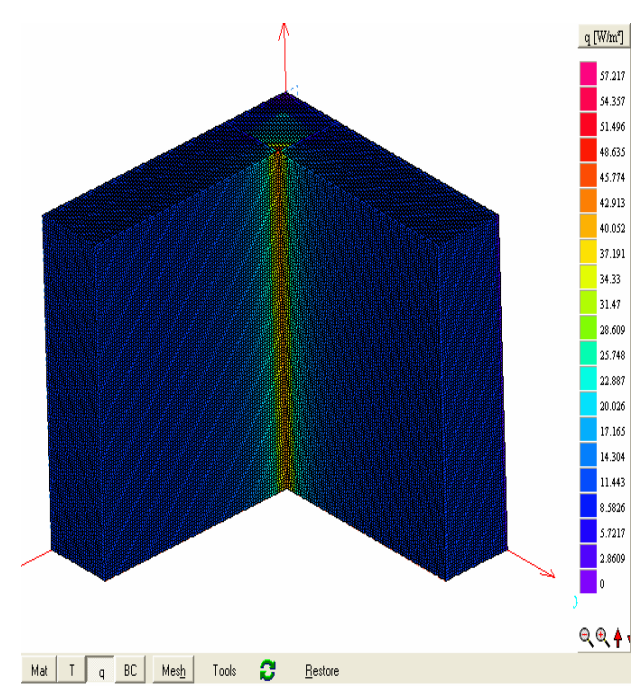

Figure $5 \mathrm{~b}$. Thermal insulated outer walls intersection (THREE DIMENSIONAL DENSITY OF HEAT FLOW DISTRIBUTION)

The results are summarized in Table 2, 3 and 4, and show the following parameters:

-Specific thermal resistance in current field of building element, $\mathrm{R}$, in $\left(\mathrm{m}^{2} \mathrm{~K}\right) / \mathrm{W}$

-Number of computational cells in HEAT3,

-Heat flow of three-dimensional steady state heat transfer using HEAT3, in W,

-Linear thermal transmittance, $\Psi$, in $\mathrm{W} /(\mathrm{mK})$. 
洫 DE GRUYTER

\begin{tabular}{|c|c|c|}
\hline \multirow[t]{2}{*}{$\begin{array}{c}\text { Case/ } \\
\text { parameters }\end{array}$} & \multicolumn{2}{|c|}{ Intersection of outer walls } \\
\hline & $\begin{array}{l}\text { Without } \\
\text { thermal } \\
\text { insulation }\end{array}$ & $\begin{array}{c}\text { With thermal } \\
\text { insulation }\end{array}$ \\
\hline $\begin{array}{l}\text { Number of computational cells } \\
\text { (HEAT3) }\end{array}$ & $\begin{array}{c}3420 \\
\mathrm{~N}_{\mathrm{x}}=9 \\
\mathrm{~N}_{\mathrm{y}}=20 \\
\mathrm{~N}_{\mathrm{z}}=19\end{array}$ & $\begin{array}{c}3420 \\
\mathrm{~N}_{\mathrm{x}}=9 \\
\mathrm{~N}_{\mathrm{y}}=20 \\
\mathrm{~N}_{\mathrm{z}}=19\end{array}$ \\
\hline Heat flow, $\Phi$, HEAT3 $[W]$ & 133.94 & 43.19 \\
\hline $\begin{array}{l}\text { Specific thermal resistance in } \\
\text { field, } \mathrm{R}\left[\left(\mathrm{m}^{2} K\right) / \mathrm{W}\right]\end{array}$ & 0.982 & 3.255 \\
\hline $\begin{array}{l}\text { Linear thermal transmittance, } \Psi \\
{[W /(m K)]}\end{array}$ & 0.1554 & 0.0751 \\
\hline
\end{tabular}

Table 2. Outer walls intersection parameters

\begin{tabular}{|c|c|c|}
\hline \multirow{3}{*}{$\begin{array}{c}\text { Case/ } \\
\text { parameters }\end{array}$} & \multicolumn{2}{|c|}{ Inner and outer wall intersection } \\
\hline & & $t=$ \\
\hline & $\begin{array}{l}\text { Without thermal } \\
\text { insulation }\end{array}$ & $\begin{array}{l}\text { With thermal } \\
\text { insulation }\end{array}$ \\
\hline $\begin{array}{l}\text { Number of computational } \\
\text { cells (HEAT3) }\end{array}$ & $\begin{array}{l}291593 \\
N_{x}=79 \\
N_{y}=129 \\
N_{z}=103\end{array}$ & $\begin{array}{l}358028 \\
N_{x}=84 \\
N_{y}=129 \\
N_{z}=103\end{array}$ \\
\hline Heat flow, $\Phi$, HEAT $3,[W]$ & 180.25 & 49.94 \\
\hline $\begin{array}{l}\text { Specific thermal resistance in } \\
\text { field, } R\left[\left(m^{2} K\right) / W\right]\end{array}$ & 0.982 & 3.255 \\
\hline $\begin{array}{l}\text { Linear thermal } \\
\text { transmittance, } \Psi[\mathrm{W} /(\mathrm{mK})]\end{array}$ & 0.1384 & 0.0084 \\
\hline
\end{tabular}

Table 3. Inner and outer wall intersection parameters

\begin{tabular}{|c|c|c|}
\hline \multirow{4}{*}{$\begin{array}{c}\text { Case/ } \\
\text { parameters }\end{array}$} & \multicolumn{2}{|c|}{ Outer wall and intermediate floor } \\
\hline & & $E$ \\
\hline & \multicolumn{2}{|c|}{ 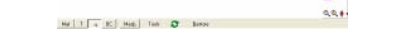 } \\
\hline & $\begin{array}{c}\text { Without thermal } \\
\text { insulation }\end{array}$ & $\begin{array}{l}\text { With thermal } \\
\text { insulation }\end{array}$ \\
\hline $\begin{array}{l}\text { Number of computational } \\
\text { cells (HEAT3) }\end{array}$ & $\begin{array}{c}583424 \\
\mathrm{~N}_{\mathrm{x}}=95 \\
\mathrm{~N}_{\mathrm{y}}=128 \\
\mathrm{~N}_{\mathrm{z}}=126\end{array}$ & $\begin{array}{c}726400 \\
\mathrm{~N}_{\mathrm{x}}=103 \\
\mathrm{~N}_{\mathrm{y}}=128 \\
\mathrm{~N}_{\mathrm{z}}=126\end{array}$ \\
\hline Heat flow, $\Phi$, HEAT3, $[W]$ & 85.24 & 19.09 \\
\hline $\begin{array}{l}\text { Specific thermal resistance, } \\
\left.\mathrm{R}\left(m^{2} K\right) / W\right]\end{array}$ & 0.982 & 3.255 \\
\hline $\begin{array}{l}\text { Linear thermal } \\
\text { transmittance, } \Psi[\mathrm{W} /(\mathrm{mK})]\end{array}$ & 0.5292 & 0.0140 \\
\hline
\end{tabular}

Table 4. Outer wall and intermediate floor intersection parameters

\section{CONCLUSIONS}

The determination of heat flows, respectively, transmission heat losses through the building envelope, through thermal bridges zones of construction elements are needed to assess the energy performance of buildings in the context of designing energy efficient buildings and thermal rehabilitating the existing building stock, as an implementation of EU Directives on energy performance of buildings.

The heat transfer evaluation using programs for threedimensional heat transfer is a key for a more accurate evaluation of the thermal bridges effect required to be precisely known and reduced as much as possible for an energy efficient building.

Moreover, modelling specific details of the most common types of building structures using three-dimensional heat transfer simulation programs such as HEAT3, it can be created a database encompassing the effect of thermal bridges through linear thermal transmittance to help designers evaluate and avoid several thermal bridges at the design phase of a new building and also to indicate the appropriate thermal insulation solution of an existing building.

\section{REFERENCES}

Pescari S., Stoian V. Tudor D., Maduta C. 2015, Energy demands of the existing collective buildings with bearing structure of large precast concrete panels from Timisoara, Journal Of Applied Engineering Sciences, I.S.S.N. 2284-7197.

Auline R., Joseph V., Jean-Jacques R., 2016, Impact of sun patch and three-dimensional heat transfer descriptions on the accuracy of a building's thermal behavior prediction, Building Simulation - An International Journal, June 2016, Volume 9, Issue 3, pp 269-279, ISSN: 1996-3599 (Print) 1996-8744 (Online).

Directive 2002/91/EC of the European Parliament and of the Council of 16 December 2002 on the energy performance of buildings.

C107, 2005, Romanian normative on thermo-technical calculation of structural components of buildings.

Mc001/2006, 2006, Energy performance of buildings determination methodology.

Buildings Thermal Bridges Catalogue, 2012, Annex to the Order no. $1590 / 24.08 .2012$.

Blomberg Thomas, 1988, Manual of HEAT3.

Brata S., Ostafe. P. G., 2015, Thermotechnics. Theory and applications, Vol.1, Politehnica Publisher, Timisoara.

Pescari S, 2015, PhD Thesis, Studies and researches on energy performance of the buildings based on sustainability, Editura Politehnica.

Thermal bridges in building construction, 2007, Heat flows and surface temperatures - Detailed calculations (ISO 10211:2007). 
Blomberg T, 1996. Heat conduction in two and three dimensions: Computer modelling of building physics applications. $\mathrm{PhD}$ Thesis, Lund Institute of Technology, Sweden.

McAdams WH., 1954. Heat Transmission. New York: McGraw-Hill Kogakusha.

Pescari S., Dan. D. Stoian V., 2013, Using the laser scanning technology in the rehabilitation of existing buildings, Proceedings of ${ }^{2}$ nd International Conference on Structures and Architecture - Structures and Architecture: Concepts: Applications And Challenges, Guimaraes, PORTUGAL, JUL 24-26, 2013, pp. 1135-1142.

Morrison. H, 2001, Thermal Performance of Building Envelope Details for Mid- and High-Rise Buildings (1365-RP).

Heat conduction in two and three direction, http://www.buildingphysics.com/manuals/avh_TB.pdf

(view at 22 March 2016).

Thermal performance of buildings http://mnre.gov.in/solarenergy/ch4.pdf (view at 27 March 2016).

\section{ACKNOWLEDGEMENTS}

This work was supported by a grant of the Romanian National Authority for Scientific Research, CNDI-UEFISCDI; project number PN-II-PT-PCCA-2011-3.2-1214-Contract 74/2012. 